DOI 10.15290/cnisk.2021.01.10.13

JUSTYNA GRANATOWSKA

https://orcid.org/0000-0003-4731-3832

Instytut Studiów Kobiecych

\title{
Sprawozdanie z Ogólnopolskiej Konferencji Naukowej „Ruchy kobiece na ziemiach polskich w XIX i XX w. Stan badań i perspektywy (na tle porównawczym)", Białystok-Augustów 11-14 września 2020 r. ${ }^{1}$
}

W dniach 11-14 września 2020 r. odbyła się ogólnopolska konferencja naukowa pt. Ruchy kobiece na ziemiach polskich $w$ XIX $i X X w$. Stań badań i perspektywy (na tle porównawczym). Wydarzenie to zorganizowane zostało przez Ośrodek Badań Historii Kobiet Instytutu Studiów Kobiecych przy współpracy z Zakładem Historii Kultury, Myśli i Ruchów Społecznych Uniwersytetu w Białymstoku. Ze względu na znaczna liczbę prelegentów, a także szeroki zakres poruszanej tematyki, obrady podzielono na kilka paneli dyskusyjnych, które pierwszego dnia odbyły się w Uniwersyteckim Centrum Kultury UwB, natomiast w pozostałych - w Oficerskim Yacht Clubie w Augustowie.

Konferencje poprzedziło uroczyste otwarcie wystawy pt. PIONIERKI. Kobiety $w$ edukacji i nauce, które nastapiło 11 września

\footnotetext{
Sprawozdanie przygotowane w ramach programu Ministra Nauki i Szkolnictwa Wyższego pod nazwa DIALOG w latach 2019-2021. Jest wynikiem udziału w projekcie badawczym pt. „Ośrodek badań historii kobiet”, nr 0016/DLG/2019/10.
} 
2020 r. na placu Syntezy w kampusie UwB. Wydarzenie to uświetniła obecność m.in. dr Anny Budzanowskiej - wiceminister nauki i szkolnictwa wyższego, prof. dr. hab. Roberta Ciborowskiego, rektora Uniwersytetu w Białymstoku, dr. hab. inż. Marty Kosior-Kazberuk, prof. PB - rektora Politechniki Białostockiej, Bohdana Paszkowskiego, wojewody podlaskiego, a także dr. hab. Tomasza Mojsika - dziekana Wydziału Historii i Stosunków Międzynarodowych UwB. Wystawa miała na celu przybliżenie sylwetek wybitnych kobiet trudniących się różnymi profesjami w ciagu lat, które swoimi poczynaniami w znaczny sposób przyczyniły się do rozwoju nauki i edukacji. Wśród bohaterek wystawy wymienić można zarówno przedstawicielki regionu Białostocczyzny, np. Irenę Białównę, jak i kobiety znane i poważane w szerszych kręgach - krajowych oraz międzynarodowych, chociażby Marię Skłodowską-Curie czy Elizę Orzeszkowa. Wystawę współfinansowało MNiSW w ramach programu „Społeczna odpowiedzialność nauki”, a przygotował Instytut Studiów Kobiecych we współpracy z Zakładem Historii Kultury, Myśli i Ruchów Społecznych Uniwersytetu w Białymstoku. Po wernisażu wystawy, a także panelu dyskusyjnym nawiąującym do ekspozycji wystawy, nastapiła inauguracja obrad konferencyjnych w Uniwersyteckim Centrum Kultury na terenie kampusu UwB.

Pierwszy panel obrad konferencyjnych rozpoczał się wystąpieniem prof. Adama Miodowskiego $z$ Uniwersytetu w Białymstoku pt. Środowiska naukowe zwiazane z Instytutem Studiów Kobiecych $w$ Białymstoku $i$ ich wkład we wspótczesne polskie badania $z$ zakresu historii kobiet (2011-2020). Prelegent wskazywał na aktywne działania organizacji na wielu płaszczyznach, zwiąane $z$ promocją i upowszechnianiem badań historii kobiet, a także wskazał na istotne osiagnięcia Instytutu, jak prowadzenie wieloletniego cyklu debat naukowych Kobiety $w \dot{z} y c i u$ publicznym, konferencji naukowych o charakterze ogólnopolskim - Polityka i politycy $w$ prasie $X X$ i XXI $w$. Szczególnie uwypuklona została kwestia utworzenia "Czasopisma Naukowego Instytutu Studiów Kobiecych”, a także powołania Ośrodka Badań Historii Kobiet, zrzeszającego w swoich szeregach badaczy $z$ ośrodków naukowych $z$ całej Polski.

Jako druga wystapiła prof. Teresa Chynczewska-Hennel, również przedstawicielka Uniwersytetu w Białymstoku, która przedstawiła referat pt. Kobiety $w$ Kasie Mianowskiego (głos $w$ dyskusji). Prelegentka ukazała historię największej i jednocześnie 
najważniejszej polskiej organizacji naukowej, która od samego początku działalności do dzisiaj skupiona jest na realizacji tych samych celów - chęci niesienia pomocy młodym naukowcom, przejawiająca się $\mathrm{w}$ realizacji programów stypendialnych, oraz we wspieraniu wydawnictw naukowych. Wskazane również zostało, jak wiele wybitnych współczesnych badaczek i naukowców związanych jest $z$ ta instytucja obecnie - jako przykład podano postacie m.in. Marii Ossowskiej, Joanny Schiller-Walickiej czy Janiny Jóźwiak.

Autorem następnego wystąienia był prof. Uniwersytetu Warszawskiego - Andrzej Hennel, który zaprezentował referat pt. Problemy z Nagrodami Nobla dla Marii Skłodowskiej-Curie (głos $w$ dyskusji). Prelegent wskazywał, że mimo wybitnych osiagnięć polskiej badaczki prestiżowa Nagroda Nobla, której przyznanie z cała pewnością jej się należało, nie było czymś oczywistym $z$ powodu płci Skłodowskiej-Curie. Polska fizyk i chemik, zostając uhonorowana tym wyróżnieniem dwukrotnie, niejako przetarła szlaki w tej dziedzinie innym kobietom. Wystapienie zakończone zostało twierdzeniem, że mimo polskiego pochodzenia Skłodowska-Curie często postrzegana jest na arenach międzynarodowych jako Francuzka. Dowodem na to było przytoczenie listy Le Plus Grand Français de tous les temps, zestawiającej najwybitniejszych Francuzów wszech czasów, w której sylwetka Marii Skłodowskiej-Curie uplasowana została na czwartej pozycji.

Następnym prelegentem był prof. Robert Suski, reprezentujacy Uniwersytet w Białymstoku, który wystapił $\mathrm{z}$ referatem pt. Kobieta, miłość i władza z nagroda $w$ tle. „Eristatos odkrywa przyczyne choroby Antiocha" Jacques'a-Louis Davida. Historia hellenistyczna ukazana na obrazie, a która przytoczył autor wystapienia, opowiadała o romantycznej nieszczęśliwej miłości Antiocha I Sotera do swojej macochy Stratonike. Niemożność wyznania swoich prawdziwych uczuć i pragnień doprowadziła bohatera do choroby zagrażającej jego życiu. Szczęśliwie ojciec bohatera - Seleukos, mając na względzie dobro własnego dziecka, postanawia oddać swoja żonę synowi w celu poprawy jego stanu zdrowia. Prelegent opisał realne przyczyny wskazujące, dlaczego rozwód władcy w tej sprawie przyniósł korzyści polityczne, a także zwracał uwagę na fakt dekonstrukcji tej wyidealizowanej historii przez współczesnych historyków.

Kolejne wystapienie, zatytułowane Katarzyna Luter $z d$. von Bora (1499-1552) - kobieta, która dokonała wyboru. Losy żony 
reformatora, wygłosiła mgr Magdalena Gąsowska. Prelegentka wskazywała na bardzo lakoniczne traktowanie żony Marcina Lutra w literaturze, zaznaczając, że najczęściej wskazywane sa jedynie daty jej narodzin, ślubu $z$ reformatorem oraz śmierci. $W$ referacie podkreślono, jak krzywdzące jest to dla osoby, która samodzielnie zadecydowała o swoim losie w patriarchalnym społeczeństwie uciekajac $z$ klasztoru i porzucając narzucona jej przez rodzinę rolę, a w późniejszym okresie będącej cichą bohaterką domostwa Lutra, mająca na niego ogromny wpływ, wspierająca i opiekująca się gospodarstwem. Zdaniem prelegentki Katarzyna Luter niewatpliwie może być traktowana jako wzór feministki oraz pionierki.

Autor następnego wystapienia - mgr Krzysztof Kossakowski wygłosił referat pt. Udział kobiet $w$ ruchach $i$ fakcjach politycznych $w$ Polsce XVI-XVIII $w$. Przedstawione zostały sylwetki kobiet pełniących istotne funkcje polityczne w Rzeczypospolitej w walkach fakcyjnych, m.in. Bonę Sforzę, Annę Jagiellonkę, Marię Ludwikę Gonzagę, Marię Kazimierę oraz Izabelę Czartoryską. Mimo że postacie te nie zasiadały w sejmie i senacie, dzięki licznym sojuszom i wielości stronników były w stanie w znaczny sposób wpływać na podejmowanie decyzji przez przedstawicieli obu izb. Wśród zaprezentowanych bohaterek odnaleźć można było sylwetki kobiet cieszacych się poważaniem i wpływami - zarówno królowe, jak i przedstawicielki wysoko postawionej arystokracji.

Przedostatnia prelekcja pierwszego panelu prowadzona przez dr Joannę Gajdę zatytułowana została Ruchy kobiece i aktywność kobiet jako przedmiot badan - szanse i wyzwania. Prelegentka podkreślała kwestie trudności metodologicznych związanych $z$ prowadzeniem badań nad działalnościa kobiet $z$ powodu mnogości ich aktywności oraz różnorodności dyscyplin, jakimi się paraja. Szczególnie mocno zaznaczyła konieczność prawidłowego dokonania procesu operacjonalizacji przedmiotu, który umożliwia dobranie odpowiednich metod i technik badawczych w celu uzyskania satysfakcjonujących danych. Referentka uwypukliła również, jakie trudności może napotkać osoba zainteresowana prowadzeniem badań społecznych tyczących się tematyki kobiet i ich działalności.

Referat zamykajacy panel pt. Ruchy kobiece $w$ Rosji na przełomie XIX i XX w. wygłosiła dr Beata Goworko-Składanek. Prelegentka wskazywała na istotne wydarzenia historyczne, które umożliwiały rosyjskim kobietom dążenie do emancypacji, zmiany pozycji 
kobiety w społeczeństwie, odejście od stereotypu wskazującego ja jako w pełni podporządkowaną w każdej sferze życia mężczyźnie. Szczególnie podkreślone zostało znaczenie reformy Aleksandra II, która dawała kobietom możliwość kształcenia się na uczelniach wyższych. Prelegentka w swoim wystapieniu poruszyła również wątek początków prasy kobiecej na ziemiach rosyjskich, uwypuklając jej bardziej edukacyjny niż rozrywkowy charakter.

Obrady pierwszego dnia konferencji zakończyła merytoryczna, ponad godzinna, dyskusja nad wygłoszonymi referatami.

Drugi dzień obrad konferencyjnych otwierali mgr Katarzyna Świetlik i mgr Paweł Woś referatem pt. „Gdzie kilka kobiet weźmie sie za sprawe...", czyli emancypacja na przykładzie Marii Dulębianki. Prelegenci wskazywali na niezwykle szeroko zakrojona działalność społeczna polskiej malarki, pisarki oraz publicystki na rzecz uzyskania równouprawnienia kobiet. Szczególnie uwypuklona została agitacja Dulębianki w sprawie dopuszczenia kobiet do pobierania nauk na akademiach sztuk pięknych. Ponadto bohaterka wystapienia uczestniczyła w wyborach do Sejmu, zakładała stowarzyszenia działające na rzecz kobiet, kierowała instytucjami charytatywnymi obejmującymi swoim działaniem tzw. dzieci ulicy, ludzi biednych oraz chorych jeńców polskich.

Kolejna uczestniczka panelu była prof. Halina Parafianowicz z Uniwersytetu w Białymstoku, która przedstawiła referat pt. „Women: This is Your Job!": Amerykanki w I wojnie światowej. Wystapienie opierało się na przeglądzie okładek poczytnego amerykańskiego periodyku „The Ladies Home Journal”, który diametralnie zmienił narrację na czas 18 miesięcy, kiedy to Amerykanie przystapili do pierwszej wojny światowej. Prelegentka opisała proces mobilizacji sił i środków oraz wiele różnych form obywatelskiej i patriotycznej aktywności amerykańskich kobiet w obliczu włączenia ich narodu do działań wojennych. Wśród nich wyróżnić można było m.in. akcje gromadzenia i umiejętnego rozporządzania żywnościa, wstępowanie do wojska celem wykonywania zawodów pielęgniarek, stenografistek, szoferów czy też organizowanie wsparcia dla kobiet, które nie były w stanie poradzić sobie samodzielnie np. $z$ prowadzeniem gospodarstwa rolnego.

Następnie prelekcję o tytule Redaktorki „Mojej Przyjaciótki” (1934-1939) i „Przyjaciółki” (w okresie Czytelnikowskim i pierwszych latach $w$ RSW „Prasa”) wygłosiła dr Katarzyna Wod- 
niak z Uniwersytetu Kazimierza Wielkiego w Bydgoszczy. Prelegentka uchwyciła znaczące różnice $\mathrm{w}$ wykształceniu oraz doświadczeniu zawodowym między redaktorkami dwóch analizowanych periodyków. Redaktorki „Mojej Przyjaciółki” przedstawione zostały jako młode, blisko dwudziestoletnie dziewczęta, bez kierunkowego wykształcenia, które „warsztat dziennikarski” zdobywały, dopiero rozpoczynając pracę w redakcji, podczas gdy kadra „Przyjaciółki” - starannie wyselekcjonowana, doświadczona w pracy dziennikarskiej - charakteryzowała się starannym przedwojennym wyższym wykształceniem oraz pochodzeniem $z$ komunistycznych inteligenckich domów.

Trzeci referat pt. Zwiazek Legionistek Polskich (1921-1939) - działalność szkoleniowa, charytatywna i kultywowanie tradycji niepodległościowych wygłosiła dr Anna Marcinkiewicz-Kaczmarczyk, reprezentująca Instytut Pamięci Narodowej w Warszawie. Prelegentka omówiła wiele statutowych aktywności rozwijanych przez ugrupowanie, m.in. udzielanie szeroko rozumianej pomocy byłym członkiniom Ochotniczej Ligi Kobiet przez zapewnianie im wsparcia moralnego i materialnego, objęcie opieką inwalidów, rodzin zmarłych i poległych w walce legionistek, a ponadto pomocy w znalezieniu zatrudnienia, uzyskania świadczeń socjalnych, jak renty, emerytury czy odszkodowania. Wspomniane zostały również działania formacji skierowane na popularyzację $\mathrm{w}$ społeczeństwie wiedzy na temat ZLP i OLK poprzez organizację zjazdów i imprez $\mathrm{z}$ okazji rocznic, a także udział $\mathrm{w}$ uroczystościach o charakterze państwowym.

Wystapienie zamykajace drugi panel tego dnia zatytułowane Kobiety artystki na łamach międzywojennego tygodnika „Kultura” (1936-1939) zaprezentowała mgr Emilia Pobocha, która przybliżyła strukturę periodyku oraz opisała tematykę, jaka podejmował, ze szczególnym naciskiem na kwestie treści o charakterze artystycznym. Wskazała, że zdecydowana większość artykułów traktujących o tej materii tyczyła się artystów mężczyzn, jednakże zdarzały się również takie, które poświęcone były przedstawicielkom płci żeńskiej - zarówno aktorkom, piosenkarkom, pisarkom, jak i baletmistrzyniom. Referentka opisała pokrótce sylwetki artystek, które prezentowano $\mathrm{w}$ badanym przez nią tygodniku, m.in. Janinę Hubertowa, Anielę Szlemińska, Stanisławę Zawadzka, Zofię Fedyczkowską czy też Jadwigę Fontanównę. 
Po zakończeniu panelu otworzono dyskusję, podczas której uczestnicy konferencji mieli okazję zadać pytania dotyczące zaprezentowanych referatów oraz wymienić się spostrzeżeniami.

Druga część obrad konferencyjnych tego dnia rozpoczęła się referatem prof. Magdaleny Mikołajczyk, reprezentującej Uniwersytet Pedagogiczny im. KEN w Krakowie, zatytułowanym Kontestator$k i$. Formy zaangażowania kobiet $w$ Polsce po 1945 roku. Referentka określiła kontestacje mianem sprzeciwu, który wyrażany jest publicznie zarówno poprzez zachowanie, jak i wypowiedzi ustne. Przytoczyła przykłady $z$ historii Polski, w których kontestacja kobiet przyjmowała różne formy opozycji i oporu społecznego, odnoszące się najczęściej do systemu politycznego. Jako przykład podano okres PRL-u, kiedy kobiety zajmowały się np. dystrybucją zakazanej prasy, przemycaniem i przechowywaniem w ukryciu niedozwolonych przedmiotów czy też braniu udziału w uroczystościach o charakterze religijnym czy patriotycznym objętych zakazem przez komunistów.

Kolejna prelekcję o tytule Rzeczywistość kobiet stanu wojennego przedstawiła prof. Jolanta Chwastyk-Kowalczyk z Uniwersytetu Jana Kochanowskiego w Kielcach. Prelegentka w swoim referacie posłużyła się korespondencja pochodzaca od S.N. - jednego z założycieli Niezależnego Zrzeszenia Studentów na Politechnice Wrocławskiej. $Z$ przytoczonych listów poznać można było nie tylko historię osadzonego działacza opozycyjnego, ale także pośrednio kobiet znajdujących się w jego otoczeniu. Badaczka wskazywała na ich ogromne poświęcenie $\mathrm{w}$ tamtym okresie, kiedy ryzykując często swoim życiem, podejmowały się niebezpiecznych działań w celu walki $z$ wrogim systemem. Podane zostały przykłady przemycania do miejsc osadzenia mężczyzn zakazanych przedmiotów, organizowanie i dostarczanie paczek, kolportaż prasy tzw. drugiego obiegu, a także wynoszenie od osadzonych materiałów, które nie mialy prawa dostać się poza obręb obiektów zamkniętych - tekstów, piosenek, grafik, rysunków o charakterze politycznym. Istotne było również zaznaczenie przez prelegentkę faktu, że kobiety w sytuacjach krytycznych przejmowały rolę „głowy rodziny” - utrzymując ja zarówno finansowo, jak i wspierając duchowo.

Trzeci referat pt. Feminizm na lamach "Kobiety $i$ Życia” (1970-1989) wygłosiła dr Urszula Sokołowska, reprezentujaca Uniwersytet w Białymstoku. Prelegentka podkreśliła, że w wypadku artykułów pochodzących $z$ badanego periodyku należy mówić raczej 
o podejmowaniu tematów równouprawnienia niż o radykalnym głoszeniu haseł feministycznych. Przypomniała wyniki plebiscytu „Emancypantka” tyczaccego się indywidualnego podejścia kobiet do kwestii, jaką i ile ról chcą odgrywać w życiu: czy jedynie gospodyni domowej (i jednocześnie matki), pracownika zawodowego, czy też obie. Prelegentka zaznaczyła również, że tematyka równouprawnienia szczególnie często była podejmowana łamach pisma w 1975 r. - podczas obchodów Międzynarodowego Roku Kobiet, oraz w latach 1975-1985, kiedy periodyk relacjonował wydarzenia towarzyszące Dekadzie Kobiet ONZ.

Opracowanie pt. Obraz Ligi Kobiet na łamach prasy dla kobiet w okresie gomułkowskim (1956-1970) zaprezentował dr Łukasz Jędrzejski z Uniwersytetu Marii Curie-Skłodowskiej w Lublinie. Prelegent wskazał, że prasę kobiecą w badanym okresie traktowano jako element systemu medialnego PRL, za pomoca którego możliwe było dotarcie $z$ istotnymi dla partii przekazami. Periodykiem promującym Ligę Kobiet było „Zwierciadło”, które miało za zadanie budować masowy obraz tej organizacji. W wystapieniu wskazane były wybrane aktywności Ligi Kobiet, m.in. działalność na rzecz środowiska społecznego, tworzenie poradni prawnych wspomagajacych kobiety w sprawach alimentacyjnych czy rozwodowych. Prelegent określił również członkinie Ligi Kobiet mianem inicjatorek różnego rodzaju przedsięwzięć, jak chociażby budowy szkół i innych placówek użyteczności publicznej, a także pomników ku upamiętnieniu Millennium Państwa Polskiego.

Ostatni panel drugiego dnia konferencji zamykał referat dr Anny Szwed-Walczak, tak jak poprzednik reprezentującej Uniwersytet Marii Curie-Skłodowskiej w Lublinie, o tytule Obraz organizacji kobiecych na kamach polskiej prasy dla kobiet $w$ okresie transformacji ustrojowej. Wystapienie oparte zostało na wynikach badań analizy czasopism „Kobieta i Życie”, „Przyjaciółka” oraz „Zwierciadło”. Prelegentka wskazała, że zdecydowanie najwięcej artykułów tyczących się tematyki organizacji kobiecych wśród periodyków wydawanych w badanym okresie znajdowało się w „Zwierciadle”, które tworzone było przez Ligę Kobiet Polskich. Referentka zaznaczyła, że najczęściej podejmowanymi kwestiami były $\mathrm{m}$.in. profity płynące $z$ przynależności do organizacji, takie jak szansa na rozwój osobisty i zawodowy, lobbing interesów kobiet, oraz opisy form działalności organizacji. 
Po referacie dr Szwed-Walczak nastapiła przerwa, po której odbył się kolejny, ostatni już panel konferencji.

Jako pierwsza wystapiła w nim prof. Małgorzata Dajnowicz $z$ referatem pt. Krajowe Zjazdy Ligi Kobiet (wybrane). Referentka w szczególny sposób zaznaczyła o istotności zjazdów z $1951 \mathrm{r}$. (pierwszego), 1966 r. (czwartego), 1981 r. (ósmego) i 1986 r. (dziewiątego). Wskazała również ważniejsze wydarzenia $z$ historii Ligi Kobiet, które znacząco wpłynęły na sposób działania organizacji. Wśród nich wyróżnić można było zmiany w programach ramowych Ligi - modyfikacje priorytetowych zadań przewidzianych do realizacji przez władze socjalistyczne, decyzje o angażowaniu się - bądź nie - w różnego rodzaju sprawy społeczne, a także przekształcanie oficjalnego nazewnictwa organizacji.

Drugi z kolei wykład Światowa Konferencja Dekady Kobiet ONZ - Kopenhaga 1980. Analiza stanowiska delegacji polskiej wygłosiła dr Edyta Chrobaczyńska-Plucińska z Uniwersytetu Pedagogicznego im. KEN w Krakowie. Prelegentka wskazała, że zarówno druga edycja Konferencji, która miała miejsce w Kopenhadze, jak i wcześniejsza z 1957 r. z Meksyku i kolejna w Nairobi z roku 1985 pozwoliły na ujawnienie i zaprezentowanie szerszej - międzynarodowej - opinii publicznej problemów, $z$ jakimi borykały się kobiety żyjące w różnych częściach globu. Było to niezwykle istotne w zwiąku $z$ dysproporcjami, jakie występowały między poziomem, stylem życia i przywilejami kobiet $z$ bloku wschodniego oraz tych $z$ tzw. Zachodu. Tematem przewodnim Konferencji $z$ Kopenhagi było zatrudnienie, zdrowie oraz edukacja kobiet, a jej hasłem przewodnim „Równość - Rozwój - Pokój”. Referentka podkreśliła, że zamierzone do osiagnięcia przez delegację polską cele były tożsame $\mathrm{z}$ priorytetami całego bloku wschodniego.

Następnie mgr Agnieszka Zaniewska $z$ Uniwersytetu w Białymstoku wygłosiła referat pt. Liga Kobiet $w$ okręgu białostockim $w$ latach 1956-1975. Kierunki $i$ efekty działalności. Wystapienie oparła na danych uzyskanych $z$ analizy egzemplarzy biuletynu „Nasza Praca”, będącym jednocześnie wewnętrznym pismem instruktażowym Ligi Kobiet, oraz „Gazety Białostockiej”, przekształconej w późniejszym okresie w „Gazetę Współczesną. Prelegentka wśród aktywności Ligi Kobiet w badanym okręgu wyróżniła powołanie do życia licznych poradni prawnych, organizowanie doraźnej pomocy potrzebujacym, a ponadto szkoleń o charakterze zawodo- 
wym i tych zwiazanych $z$ tzw. stylem życia, np. dotyczących wystroju mieszkań. Wspomniała też kwestię mobilizowania się nawzajem członkiń Ligi do współzawodnictwa $z$ innymi ośrodkami w celu uzyskania miana najlepszej placówki regionalnej.

Magister Justyna Zajko-Czochańska, również z Uniwersytetu w Białymstoku, jako ostatnia w panelu zamykajacym obrady konferencyjne zaprezentowała wystapienie pt. Wybrane formy emancypacji kobiet wiejskich na łamach „Przyjaciółki” w latach 1956-1975. Referentka zwróciła uwagę na różnice w przekazie treści emancypacyjnych w wydaniach „Przyjaciółki” wiejskiej oraz jej mutacji miejskiej. W pierwotnym, skierowanym do kobiet $\mathrm{z}$ obszarów wiejskich, wydaniu w o wiele węższy sposób eksponowano tego typu treści $\mathrm{z}$ powodu konserwatywnego wychowania czytelniczek, ich zakorzenienia $\mathrm{w}$ tradycji oraz silnego powiązania $z$ Kościołem. Na lamach pisma wystosowywano apele do kobiet starszego pokolenia zachęcające je do zezwalania ich córkom na edukowanie się - uczęszczanie do techników rolniczych, branie udziału w kursach i szkoleniach o tematyce ogrodniczej oraz upowszechniajace wysyłanie potomstwa na studia. Celem takich zabiegów była próba zmiany zakorzenionych w umysłach czytelniczek stereotypów dotyczących podziału ról społecznych.

Po wystapieniu mgr Zajko-Czochańskiej nastapił czas na finalny już panel dyskusyjny, podczas którego zarówno prelegenci, jak i inni uczestnicy konferencji mieli okazję wymienić się spostrzeżeniami w nawiazaniu do wygłoszonych referatów.

Ostatni dzień konferencji rozpoczął się otwarciem panelu dyskusyjnego na temat obecnego stanu badań na temat historii kobiet w odniesieniu do publikacji „Czasopisma Naukowego Instytutu Studiów Kobiecych”. Zaznaczona została również kwestia konieczności upowszechniania oraz promocji niniejszego pisma jako forum dyskusji o charakterze naukowym na temat dziejów kobiet.

Po niemalże dwugodzinnej dyskusji merytorycznej nastąpił czas na zajęcia warsztatowe o charakterze indywidualnym, prowadzone przez prof. Małgorzatę Dajnowicz. Ich tematyka skupiała się na szeroko pojętej historii kobiet. Po zakończeniu wymiany zdań prof. Dajnowicz dokonała uroczystego zamknięcia obrad, dziękując obecnym za przybycie i jednocześnie zapraszając do wzięcia udziału w kolejnych edycjach konferencji. 